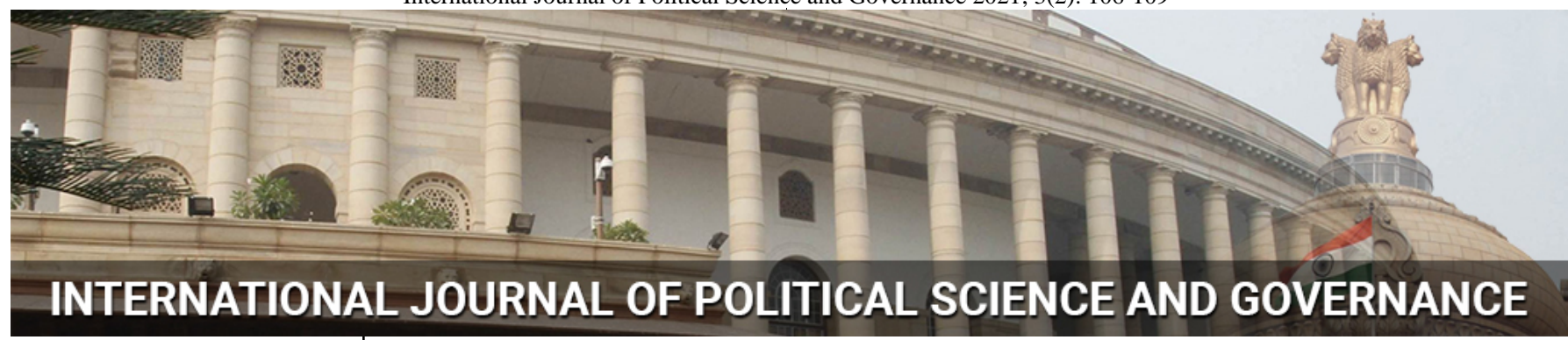

E-ISSN: 2664-603X P-ISSN: 2664-6021 IJPSG 2021; 3(2): 106-109 www.journalofpoliticalscience.com Received: 26-08-2021 Accepted: 05-10-2021

\section{Shivangi Basu}

Undergraduate Student, Pursuing Bachelor of Arts (Honours) in Political Science, Lady Shri Ram College for Women, University of Delhi, New Delhi, Delhi, India
Corresponding Author: Shivangi Basu

Undergraduate Student, Pursuing Bachelor of Arts (Honours) in Political Science, Lady Shri Ram College for Women, University of Delhi, New Delhi, Delhi, India

\section{Assessing India's vaccine diplomacy: An effective tool?}

\section{Shivangi Basu}

DOI: https://doi.org/10.33545/26646021.2021.v3.i2b.116

\begin{abstract}
In context of the ensuing global health crisis with the rise of the COVID-19 crisis, the international realm has been faced with a multiplicity of challenges and is experiencing a phase of transition. The relevance of the existing dominant approaches to international relations in the post-pandemic world has been subjected to questioning. State and non-state actors have adopted newer and more innovative strategies to pursue and promote their national interests in the global stage. Health diplomacy has emerged as a particularly prominent domain shaping the foreign policy strategies and diplomatic endeavours of states. In this context, this paper tries to examine India's strategy of 'vaccine diplomacy' and evaluate how effective it has been for India's political and social dynamics in the long run.
\end{abstract}

Keywords: Vaccine Diplomacy, Covid-19, India, Foreign Policy, Vaccine Maitri.

\section{Introduction}

In light of the global pandemic and its large scale impact which has penetrated every sphere of human society, the world has encountered major changes particularly in the field of diplomacy, foreign policy and international politics. The world order has witnessed armed conflict, escalating diplomatic tensions and restrictions on borders and the free movement of people, trade and goods during this period. The global health crisis has provoked academic conversations on the relevance of the existing dominant approaches to international relations in the post-pandemic world. Health diplomacy, politics of crisis and international aid and cooperation in emergencies have emerged as prominent issues shaping the foreign policy strategies and diplomatic endeavours of states. In this context, it is paramount to examine one of India's contemporary strategies as an actor on the international stage- 'vaccine diplomacy'.

Vaccine diplomacy, simplistically, can be defined as, the use of supply and delivery of vaccines by a country as a diplomatic tool. The concept of 'vaccine diplomacy', while certainly a contextually innovative move, is as old as vaccines itself. Vaccine diplomacy has historically played a significant role in the dynamics of international politics during times of global health crises and epidemics.

World politics witnessed an interesting development with the rollout of vaccines for the Sars-CoV 2 virus- the rise of 'vaccine apartheid' [1] or 'vaccine nationalism'. This is indicative of a worldwide situation where countries are in a rush to hoard vaccine supply for domestic markets while restricting the supply for exports. Amplifying the lack of international cooperation on global health and vaccines, such trends have resulted in the creation of a new set of 'haves' and 'have not's. Wealthier countries and global superpowers have negotiated agreements with vaccine manufacturers in advance leaving states with relatively weaker economic and political power at a severe disadvantage. While the major world powers and the Global North have ensured an abundant supply of vaccines for themselves, a significant proportion of the world's population remains at risk due to lack of resources for vaccine purchases.

However, India preferred an alternative policy direction with its 'Vaccine Maitri' initiative. India's vaccine diplomacy led the path for global collaborative efforts in the circulation of vaccines on an international scale.

${ }^{1}$ Tharoor, Shashi, Rajiv Chopra, Bo Sjö, j. von Hettlingen, Sudheer.kj, Abhishek Tripathi, and P. Kamath. “India's Smart Vaccine Diplomacy by Shashi Tharoor.” Project Syndicate, March 11, 2021. https://www.projectsyndicate.org/commentary/india-covid19-vaccine-diplomacy-by-shashi-tharoor-2021-03. 
India contributes to about $62 \%$ of the global vaccine production and is widely reputed as the global 'vaccine manufacturing powerhouse'. India attempted to provide indigenous, accessible and cost effective vaccines for export. Indian low-cost, easily transportable vaccines were affordable for low-income and developing countries who could not afford expensive vaccines from pharmaceutical companies such as Pfizer and Moderna and vaccines from Russia or China.

With the onset of 2021, the Ministry of External Affairs announced its policy of 'vaccine diplomacy' wherein India would supply domestically manufactured vaccines to its neighbours and other nations in need on a priority basis. Bharat Biotech's Covaxin and Covishield manufactured by Serum Institute of India (SII), were supplied across the world. The achievements of vaccine diplomacy were demonstrated in the increased demands for Indian vaccines in countries such as Brazil and South Africa as well as Western countries such as the UK and Canada.

Within the duration of January to April 2021, India provided grants and conducted sales of a total of 663.698 lakh vaccines according to official statistics published by the Ministry of External Affairs as of May 29, 2021. India supplied vaccines to 95 sources globally including neighbouring countries such as Nepal, Bangladesh, Bhutan, UAE, Myanmar, Sri Lanka, Maldives, Afghanistan; other Asian countries such as Syria, Kuwait, Saudi Arabia, Iran; countries in other continents such as Brazil, South Africa, Algeria, Nigeria, Kenya, Paraguay, Uganda and countries of the global North such as Canada and UK to name a few. Additionally, a generous supply of vaccines was contributed to non-state actors such as the UN Peacekeepers, UN Health Workers and WHO's COVAX vaccine distribution program [2].

Vaccine diplomacy was initially perceived as a commendable move for India as it set the benchmark for a collective endeavour on a global scale to supply life-saving vaccines crucial in mitigating the global health disaster induced by the pandemic. It was considered to be a major step towards viewing vaccines as a global public good. This would counter the precedent of vaccine nationalism restricting the accessibility of vaccines for poorer countries. Inadequacy in vaccine availability is expected to prolong the pandemic-induced world health crisis and cause further disruption in global supply chains. Shortages in vaccine supply can delay post-pandemic resurgence of states further prompting global inequalities. In such a global atmosphere, India's foreign policy move has proved that international cooperation is the need of the hour to effectively overcome the pandemic.

However, India's vaccine diplomacy was not driven by purely altruistic motives. The world geopolitical order has been altering in the post-pandemic world and the traditional global North-South divide, while being intensified in some cases, has also been transcended. A prominent epitomization in this regard is India who decided to actively manufacture and export a substantial quantity of vaccines rather than becoming dependent on the West for supplies. This move is of strategic significance to Indian foreign policy as it provided an opportunity for India to regain a strong hold in the geopolitics of South Asia by re-establishing good

2 “Vaccine Supply.” Ministry of External Affairs, Government of India. Accessed July 19, 2021. https://mea.gov.in/vaccine-supply.htm. diplomatic relationships with its neighbours. According to Shashi Tharoor, India's vaccine diplomacy is an attempt to "leverage its scientific and medical skills to enhance its geopolitical standing" [3].

In particular, India pursued a 'Neighbourhood First' policy in supplying vaccine aid to countries. Countries such as Nepal, Bhutan, Sri Lanka, Bangladesh etc. were provided the vaccine benefits on a priority basis. For example, vaccine diplomacy strategies acted as a promising ground for renewing deteriorating diplomatic relations with Bangladesh and altering public opinion on India. Vaccine diplomacy allowed India to act as the immediate help for the neighbouring countries amidst the pandemic-induced crisis which could possibly renew India's influential position in South Asia thereby countering the rising tide of China.

India's vaccine assistance program represents a soft power tactic to further cement its position as a global power through its role as a provider of aid and by facilitating commercial sales of vaccines. Moreover, the initiative of vaccine diplomacy is a part of the long-standing Indian foreign policy tradition of 'development partnership' ${ }^{[4]}$ in operation since the 1950s. This is premised on a principle of cooperation with India playing the role of a development partner to other countries in meeting their needs based on a tenet of mutual gains.

Another sub-textual factor can also be identified behind India's decision to embark on a program of global assistance towards vaccine distribution- the need to counter the Chinese threat. Aggravated border tensions between India and China over the past year coupled with China's quite apparent rising influence in South Asia have made the impact of the policy of vaccine diplomacy a critical aspect which will shape India's role as a major power in regional South Asian politics. In light of Sino-Indian geopolitical tensions, India announced a mega-policy of 'Aatmanirbhar Bharat' (self-reliance) to promote local Indian-made goods domestically and internationally. In such a milieu, the commercial supply of indigenously sourced vaccines by India is a climacteric moment for India's role as a economic and political power.

Additionally, India could possibly secure another substantial benefit through vaccine diplomacy; the support of smaller, developing countries through stronger diplomatic ties may enable India to secure a permanent seat on the UN Security Council. India has for long lobbied for a permanent seat in the Security Council of the United Nations in pursuance of this strategic goal. India is set to host the G20 summit in 2023, it has also secured a non-permanent membership in the Security Council and India's role as a member of QUAD (Quadrilateral Security Dialogue) are all crucial aspects which will subsequently impact India's position as a global superpower. The recent QUAD summit in March 2021 too, included discussions on the role India would play in the new QUAD vaccine production measure in association with Johnson \& Johnson. Thus, vaccine diplomacy indicates a critical juncture for India's aspiration to be accorded the

\footnotetext{
${ }^{3}$ Tharoor, Shashi, Rajiv Chopra, Bo Sjö, j. von Hettlingen, Sudheer.kj, Abhishek Tripathi, and P. Kamath. "India's Smart Vaccine Diplomacy by Shashi Tharoor.” Project Syndicate, March 11, 2021. https://www.projectsyndicate.org/commentary/india-covid19-vaccine-diplomacy-by-shashitharoor-2021-03.

${ }^{4}$ Dhar, Biswajit. India's Vaccine Diplomacy. Global Policy Journal, April 8, 2021. https://globalpolicyjournal.com/blog/08/04/2021/indias-vaccinediplomacy.
} 
status of a world superpower.

Based on these determinants, this diplomatic endeavour was heralded as an effective policy strategy with the potential to improve India's standing regionally and globally. It was argued that India's vaccine diplomacy initiative sent a strong statement to the world. Despite the promising nature of Indian vaccine diplomacy, occurrences in the subsequent months compelled a reconsideration of the effectiveness of India's vaccine diplomacy policy.

However, vaccine exports were surceased in the latter half of April 2021 amidst the outbreak of the second wave of the pandemic within India and the shortages faced in domestic vaccine availability. India failed to deliver some of its promised vaccine supplies to other countries prioritizing domestic demand instead. India went on to face adverse conditions in the ensuing months due to the nation-wide collapse of health infrastructure, shortage of essential medical supplies and equipment along with poor vaccination rates. The conditions leading to the discontinuation of this policy initiative precipitated various postulations and arguments regarding the ineffectuality of the vaccine diplomacy strategy.

An important question raised in this regard is whether the Indian state overlooked the urgent need for vaccines nationally in pursuance of its foreign policy interests. With the onset of vaccine diplomacy, the rates of vaccine exports far exceeded the immunization rates domestically. The surge of Covid cases and the crisis situation during the second wave caused the government to face severe criticism for its diplomatic policy. Did India overestimate its pharmaceutical manufacturing capabilities which consequently were responsible for the severe shortages in vaccine availability? It has also been argued that India should have prioritized the needs of Indians and met domestic immunization targets while pursuing health diplomatic exports as a secondary goal. Furthermore, critical limitations such as the condition of the economy, the risk of a further surge in Covid cases and urgency of meeting domestic targets should have been taken into consideration before India made commitments of health-care exports overseas.

Ultimately, it can be noticed that the intensified challenges India faced in the second wave of the pandemic can be attributed to lack of prudent and foresighted policy planning, resource management. During the early months of 2021, it seemed that the government was confident in their belief that India had successfully countered the Coronavirus, which in retrospect was a hasty miscalculation. The domestic vaccination program commenced along with India's vaccine friendship diplomatic initiative; this reflects a lack of foresight on the healthcare crisis and any escalations that could follow.

The Foreign Affairs Minister S. Jaishankar has presented a cogent counter-argument; India can expect international aid only if it reciprocates the same. However, the nation-wide vaccine shortages and India's inability to supply the promised quantities of vaccines to different countries certainly demonstrate that India lacked the production capacity to continue vaccine exports along with its national vaccination drive in the long-term.

Debates over vaccine diplomacy can essentially be condensed to one critical question-should the Government of India have adopted a policy of vaccine nationalism instead of vaccine diplomacy like the US, choosing to focus on its domestic vaccine requirements on an immediate basis?

On the basis of these arguments, we can draw certain conclusions on the effectiveness of India's vaccine diplomacy. While the ensuing national catastrophe in India obscured some of the policy's initial successes, it is still conjectural to deem vaccine diplomacy a failed policy. Experts have also pointed out that vaccine diplomacy cannot be solely blamed for the Covid-19 second wave in India; the crisis may have been inevitable due to long-term mismanagement and a plethora of other factors. Even without the implementation of vaccine diplomacy, could the second wave have been deterred? The crisis was a collective failure of the Indian state which needs to be acknowledged and vaccine diplomacy may not have played such a critical role in this as it is deemed to have played.

Did vaccine diplomacy pay off for India? India found its role reversed from the provider to the receiver of essential pharmaceutical supplies in April-May 2021 receiving aid from countries such as Russia, US, France and other European countries. There was a vast difference between the countries who received aid under 'Vaccine Maitri' and those that responded during India's health crisis. It may be convenient to argue that this occurrence alone demonstrates the ineffectiveness of vaccine diplomacy; however there is yet another aspect to consider. Under 'Vaccine Maitri', India primarily extended help to low-income countries and countries in dire situations including India's smaller neighbouring states, African states etc. Many beneficiaries of vaccine diplomacy were grappling with crises themselves; can it be presumed that such countries were in a position to ship medical aid to India? Even so, for South Asian countries such as Bhutan or Bangladesh who were beneficiaries of India's vaccine diplomacy and who reciprocated by supplying emergency medical help such as Remdesivir and oxygen to India; the case may be made that due to the long-established bilateral relations with India, help would have been extended in either case ${ }^{[5]}$.

Besides, it may be premature to draw an assessment of this diplomatic effort within a short period of time given the complicated nature of diplomacy often undertaken with a long-term vision and strategic goals. After a comprehensive evaluation of this foreign policy strategy, one is drawn to the conclusion that India may still acquire prospective political gains due to 'Vaccine Maitri' in the long-run. This will be determined by the future prospects of re-initiation of vaccine diplomacy in the near future.

India has not yet clarified its position on reinstating its vaccine diplomacy policy for the immediate future at least. Moreover, the slowdown of Indian health care exports to smaller states such as Nepal and Bangladesh has created an opportunity for other countries such as Russia and China to successfully bridge the gap with their respective vaccine exports. Under such circumstances, it may be too soon to speculate about the future potential of vaccine diplomacy as a foreign policy tool for India.

\section{References}

1. Tharoor Shashi, Rajiv Chopra, Bo Sjö J, Von Hettlingen, Sudheer KJ, Abhishek Tripathi et al. India's

\footnotetext{
${ }^{5}$ Iwanek, K. (2021, May 24). Don't Write Off Indian Vaccine Diplomacy Yet. - The Diplomat. https://thediplomat.com/2021/05/dont-write-offindian-vaccine-diplomacy-yet/.
} 
Smart Vaccine Diplomacy by Shashi Tharoor. Project Syndicate 2021. https://www.projectsyndicate.org/commentary/india-covid19-vaccinediplomacy-by-shashi-tharoor-2021-03

2. Vaccine Supply. Ministry of External Affairs, Government of India. Accessed July 19, 2021. https://mea.gov.in/vaccine-supply.htm.

3. Dhar Biswajit. India's Vaccine Diplomacy. Global Policy Journal 2021. https://globalpolicyjournal.com/blog/08/04/2021/indiasvaccine-diplomacy.

4. Iwanek K. Don't Write Off Indian Vaccine Diplomacy Yet. - $\quad$ The Diplomat 2021. https://thediplomat.com/2021/05/dont-write-off-indianvaccine-diplomacy-yet/ 